\title{
Intervention programs on reading and writing processes in children with learning disorders: A review
}

\author{
Cristian Villanueva-Bonilla ${ }^{1,2 *}$ and Ángela M. Ríos-Gallardo ${ }^{1}$ \\ ${ }^{1}$ Grancolombiano Polytechnic University Institution, Bogotá; ${ }^{2}$ Young Researchers and Innovators Programme Colciencias, Universidad Surcolombiana, \\ Neiva. Colombia
}

\begin{abstract}
Reading comprehension is the goal of all reading and constitutes one of the fundamental axes of cognitive development in early childhood. The learning problems are manifested essentially in the school environment and significantly hinder academic activities that include reading and writing processes. This review identifies and compares published research on intervention processes in children with learning difficulties, specifically addressing dyslexia and dysgraphia. We selected eight studies in Spanish at a Latin American level and 23 studies in English at a global level. In conclusion, the current state of empirical research published in Spanish in intervention processes in children with learning difficulties is fewer in number in the past 10 years compared to literature in English, as evidenced by the search. The comparison established with literature published in English and worldwide indicates progressive advances of the Latin American literature in the subject addressed by this review, specifically in intervention programs focused on specific difficulties associated with learning disorders.
\end{abstract}

Key words: Learning problems. Reading comprehension. Intervention. Dyslexia. Dysgraphia.

\section{Programas de intervención sobre procesos de lecto-escritura en niños con trastornos del aprendizaje: Una revisión}

\section{Resumen}

La comprensión lectora es el objetivo de toda lectura y se constituye como uno de los ejes fundamentales del desarrollo cognitivo en la primera infancia. Los problemas de aprendizaje se manifiestan esencialmente en el ámbito escolar y obstaculizan de forma significativa las actividades académicas que incluyen procesos de lectura y escritura. La presente revisión identifica y compara las investigaciones publicadas sobre procesos de intervención en población infantil con dificultades del aprendizaje, abordando específicamente la dislexia y la disgrafia. Se seleccionaron 8 estudios en español a nivel latinoamericano y 23 estudios en inglés a nivel mundial. En conclusión, el estado actual de la investigación empírica publicada en español en procesos de intervención en población infantil con dificultades del aprendizaje son menores en número en

\section{Correspondence:}

${ }^{*}$ Cristian Villanueva-Bonilla

Faculty of Health, Surcolombian University

Hernando Moncaleano University Hospital

Calle 9, carrera 4

Date of reception: 23-08-2018

Date of acceptance: $10-11-2018$

E-mail: cristian.villanueva @usco.edu.co 1665-5044/@ 2018. Academia Mexicana de Neurología A.C. Published by Permanyer México. This is an Open Access article under the terms of the CC BYNC-ND license (http://creativecommons.org/licenses/by-nc-nd/4.0/). 
Ios últimos 10 años en comparación con la literatura en inglés, como lo evidencia la búsqueda realizada. La comparación establecida con la literatura publicada en inglés y a nivel mundial indica avances progresivos de la literatura latinoamericana en el tema abordado por esta revisión, específicamente en programas de intervención enfocados en dificultades específicas asociadas a los trastornos de aprendizaje.

Palabras clave: Problemas de aprendizaje. Comprensión de lectura. Intervención. Dislexia y disgrafia.

\section{Introduction}

Reading comprehension is the goal of all reading and is one of the fundamental axes of cognitive development in early childhood ${ }^{1}$. Reading is an active process of preparation and interpretation of written language, which produces new meanings from the union between the reader's previous information and the (interactive) text. In addition, the author defines it as a strategic process that varies according to the reader's purpose and implies control of cognitive abilities that contribute to the final comprehension of the text (metacognition)2.

Language literacy is a capacity that has recently consolidated ${ }^{3}$. Every day people are exposed to various activities where skills related to reading are implicit. However, the development of such capabilities has become a difficulty for parents, teachers, and students. The learning problems are manifested essentially in the school environment and significantly hinder academic activities that include reading and writing processes ${ }^{4-6}$.

Research in the 70s focused on describing the population with reading and writing difficulties, investigating the possibility of designing specific intervention strategies; in the 1980s, experimental research began with different strategies focused on improving the specific difficulties of learning disorders ${ }^{7}$. Later, in the 90 s, intervention programs and strategies were designed for class situations, taking as an axis the social and motivational conditions of students with such difficulties. Greater attention was given to the methods and materials teachers used to teach their students, including the necessary teaching materials and group work ${ }^{8}$.

School requirements have increased significantly in society in recent years; currently, the starting age of primary education has declined. Schooling begins before entering school, in institutions such as nursery, garden, and preschool, which serve as a prelude to formal education ${ }^{9}$. Appropriately, it has been established in the Colombian population as in other Latin American countries (Argentina, Brazil, Chile, Mexico, Peru, and Uruguay), the commitment to the improvement of reading skills through national and international initiatives aimed at the development whole of the children ${ }^{10}$.
They have been initially implemented two programs to meet the reader level assessment of children. In recent years, these programs have shown disturbing figures of Colombian and Latin American children who obtain low scores in international and national tests of reading performance ${ }^{10}$. Overall, Latin America is below in PISA scores (2000-2012) average reading and mathematics so their world regions (Eastern and Western Europe, Anglo-Saxon countries, Asia-Pacific, and Nordics $)^{10}$. However, the upward trend in average scores is an indicator of progress in skills such as reading.

Latin American countries also differ from each other, Colombia ranks sixth among the seven countries mentioned above in TERCE scores in reading for the third grade of schooling. Chile presents an average markedly superior to the other countries, followed by Uruguay, Peru, Mexico, Brazil, and finally Argentina ${ }^{10}$. Taking into account the same test (TERCE) applied in sixth grade, and for the same year, Colombia climbs to fourth place, and Chile maintains its average score. In the PISA tests (2000-2012), there is a similar situation ${ }^{10}$.

Despite the improvement evidenced in the mentioned results, the difficulties of reading and writing have had an impact on the increase of learning problems, causing school failures and generating an increase in the incidence of the diagnosis of learning disorders. School failure is directly related to difficulties in areas such as literacy and mathematics, thematic axes in most CoIombian and Latin American schools that impede the development of other skills necessary for the full development of children (kinesthetic, spatial, musical, artistic, and among others) ${ }^{11}$. In other words, education is not adapted to the cognitive, social, and emotional needs of the child ${ }^{9,12}$.

The mentioned difficulties affect the adequate capacity to read and understand a written text. For this reason, the prevalence of learning disorders in schoolchildren has increased, ranging from $15 \%$ to $20 \%$, characterized by low school performance and loss of academic years ${ }^{13}$. One of the most common diagnoses is developmental dyslexia (DD), identified as being a neuropsychological disorder that presents difficulties in phonological processing (phonological awareness and 


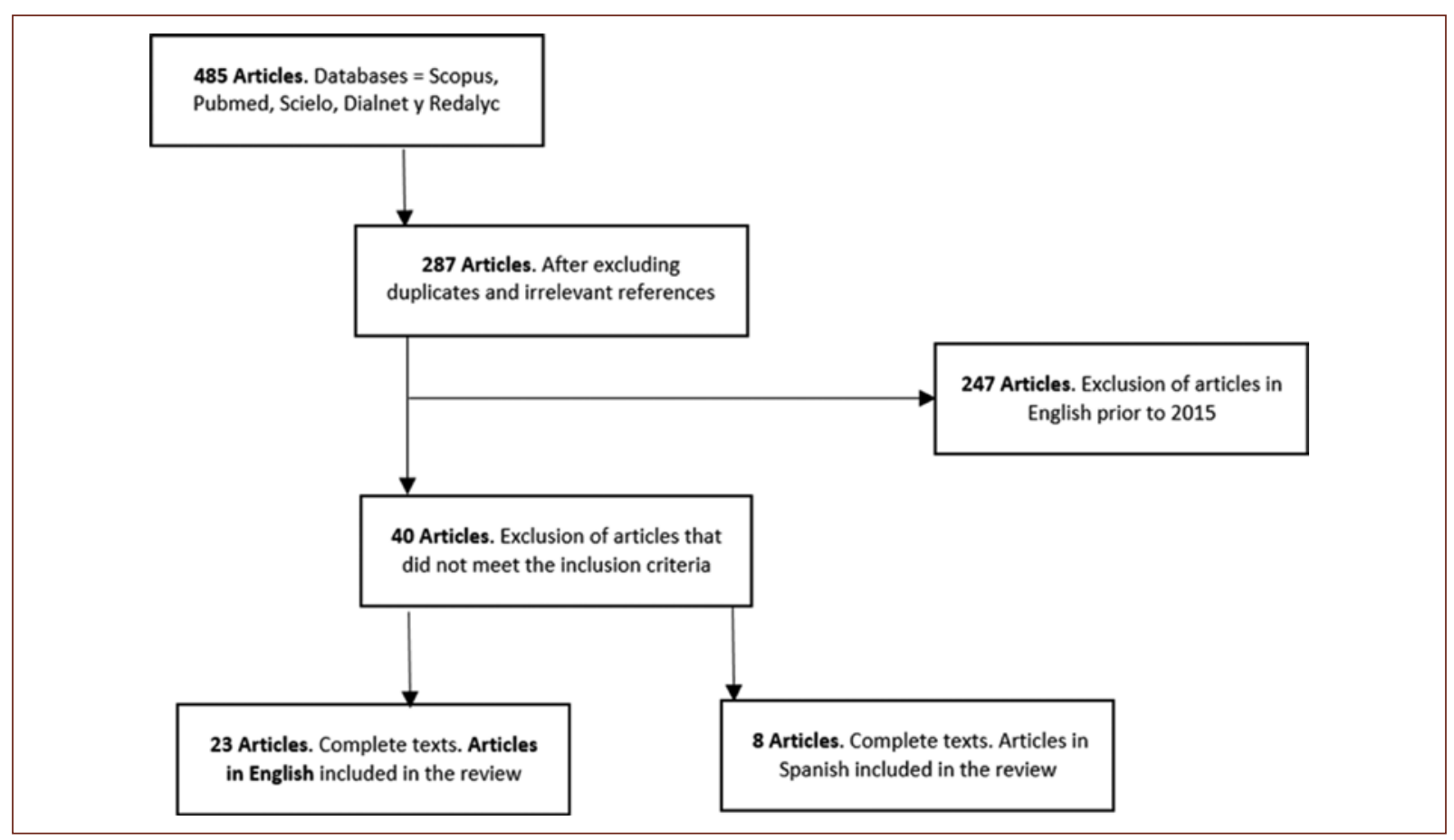

Figure 1. Flow diagram of the selection process of the studies.

mastery of grapheme-phoneme relationship) and comprising a specific difficulty of the language of neurobiological origin ${ }^{14,15}$. On the other hand, dysgraphia is characterized by difficulties in motor skills that affect the graphic quality of writing with a general origin of functional etiology ${ }^{16-18}$.

Since this is a phenomenon that requires prompt intervention by professionals in health sciences, including the psychologist, it is essential to know the different intervention processes on reading and writing skills in children with learning disorders. For this reason, the purpose of this review is to identify and compare research published in Spanish and Latin American journals in the past 10 years with publications made in English and published in different journals worldwide during the past 2 years, about processes of intervention in children with learning difficulties, specifically addressing dyslexia and dysgraphia.

\section{Methodology}

The methodology used to search for literature written in Spanish and English is described below:

\section{Search for literature}

Intervention studies written in English that was published from January 2015 to May 2016 and written in
Spanish studies were searched from January 2007 to May 2016. Figure 1 summarizes the process of study selection.

The databases consulted to identify the articles in English were Scopus, PubMed, and ScienceDirect with the following search terms: "dyslexia" or "dysgraphia" or "developmental dysgraphia" or "agraphia" or "alexia" or "developmental agraphia" or "developmental reading disorder" or "DD" or "developmental reading disability" or "reading disorder" or "spelling disorder" or "developmental spelling disorder" or "specific spelling disorder" combined with "intervention" or "training" and including the population under study, "children" or "child." The terms in English were extracted from Mesh Browser and the articles identified in the initial literature review and final selection of 23 studies of 16 journals (Table 1).

For the search in Spanish, the databases of Redalyc, Scielo, Dialnet, and the Google Scholar search engine were selected, and the following search terms were used: "dislexia," "Incapacidad Lectora Durante el Desarrollo," "Dislexia del Desarrollo," "Trastorno de la Lectura," "Alexia," "Trastorno del Desarrollo de la Lectura," "Agrafia," "Disgrafia," "Agrafia Pura," "Disgrafia del desarrollo," "Trastorno de la escritura," "Trastorno de la expresión escrita," combined with "intervención" o "entrenamiento," together with the population, "niños" o "niñ?" The terms in Spanish were extracted from descriptors in health sciences and the articles identified in the first literature 
Table 1. Indexed journals and articles in English subject of the study

\begin{tabular}{|l|l|c|}
\hline ISSN number & Title of the journal & N (articles) \\
\hline 10769242 & Dyslexia & 1 \\
\hline 02667363 & $\begin{array}{l}\text { Educational psychology in } \\
\text { practice }\end{array}$ & 1 \\
\hline 16641078 & Frontiers in Psychology & 4 \\
\hline 19411243 & $\begin{array}{l}\text { J. Occup. Ther. Sch. early } \\
\text { intervention }\end{array}$ & 2 \\
\hline 02782626 & Brain and cognition & 1 \\
\hline 00066761 & BPA applied psychology bulletin & 1 \\
\hline 21678359 & PeerJ & 1 \\
\hline 00222194 & Journal of learning disabilities & 1 \\
\hline 19326203 & Plos One & 4 \\
\hline 07369387 & Annals of dyslexia & 1 \\
\hline 22131582 & Neurolmage: clinical & 1 \\
\hline 22119493 & $\begin{array}{l}\text { Trends in neuroscience and } \\
\text { education }\end{array}$ & 1 \\
\hline 10870547 & Journal of attention disorders & 1 \\
\hline 18632653 & Brain structure and function & 1 \\
\hline 23171782 & Codas & 23 \\
\hline 00315125 & Perceptual and motor skills & 1 \\
\hline Total & & 1 \\
\hline
\end{tabular}

review. Primary studies were reviewed (clinical trial or controlled clinical trial or randomized controlled trial or case reports). Consisting of 35 articles that were found in the 22 indexed psychology journals that were consulted (Table 2) and final selection of eight studies.

\section{Criteria for the selection of studies}

For this review, the following criteria were considered: (a) the objective of the study was to identify and review the interventions carried out on the reading and writing processes in children with learning disorders; (b) the articles were written in Spanish or English; (c) primary studies (clinical trial or controlled clinical trial or randomized controlled trial or case reports) are included; and (d) the interventions were aimed at children.

\section{Organization of information}

The organization of the information was done in an excel matrix; the following information was collected
Table 2. Indexed journals and articles in Spanish found \begin{tabular}{|l|l|l}
\hline ISSN number & Title of the journal & N (articles)
\end{tabular}

\begin{tabular}{|l|l|l|}
\hline $1794-4724$ & $\begin{array}{l}\text { Avances en Psicología } \\
\text { Latinoamericana }\end{array}$ & 4 \\
\hline $0120-0534$ & $\begin{array}{l}\text { Revista Latinoamericana de } \\
\text { Psicología }\end{array}$ & 1 \\
\hline $1657-9267$ & Universitas Psychologica & 3 \\
\hline $1657-8961$ & Pensamiento Psicológico & 5 \\
\hline $0123-9155$ & Acta Colombiana de Psicología & 4 \\
\hline $0124-0137$ & Psicogente & 8 \\
\hline $0121-5469$ & $\begin{array}{l}\text { Revista Colombiana de } \\
\text { Psicología }\end{array}$ & 3 \\
\hline $2027-1786$ & $\begin{array}{l}\text { Revista lberoamericana de } \\
\text { Psicología }\end{array}$ & 1 \\
\hline $0124-7816$ & Katharsis & 1 \\
\hline $1900-2386$ & $\begin{array}{l}\text { Psychología: Avances de la } \\
\text { Disciplina }\end{array}$ & 1 \\
\hline $1900-3099$ & Pensando Psicologia \\
\hline $2145-3535$ & Informes Psicológicos & 1 \\
\hline Total & & 35 \\
\hline
\end{tabular}

from each of the studies (title, author, year, objective, sample, instruments, intervention process, results, findings, and bibliography).

\section{Results}

Once the articles of the search were selected using the aforementioned methodology (eight in Spanish and 23 in English), the following sections characterize Latin American and worldwide research at a first moment, after which the state of the research carried out is compared, including the relevance of the interventions and the results presented.

\section{Latin American literature (Spanish)}

In general, the research carried out specifically on intervention with children with learning difficulties is found in smaller numbers at a Latin American level (literature in Spanish) compared to the world literature; however, the authors referenced below focus on important aspects that contribute to the promotion of reading and writing skills, favoring the adaptation of children to their school contexts, including parents and 
teachers so that the changes made can also be present in their social context.

Initially, the execution of a neuropsychological intervention program was highlighted through game activities that sought to improve the abilities related to the reading process, such as accuracy, speed of reading, comprehension of texts, and phonological awareness. The children were evaluated through tests of cognitive assessment and IQ that showed improvement in their reading performance (child neuropsychological assessment - ENI and WISC IV) ${ }^{19}$.

In this sense, other investigations developed literacy programs focused on the phonological awareness component. Different visopráxicas activities and the spatial location were presented to strengthen the corporal and spatial scheme to generate changes in the phonological processing of the words. The authors concluded that this type of intervention programs has a positive impact on the skills that ensure success in learning to read ${ }^{20-22}$. In addition, the implementation of different activities based on materials such as board games, didactic supports is highlighted. In addition, the implementation of different activities based on materials such as board games, didactic supports and inferential questionnaires is highlighted, which allowed children to develop skills in orality and the elaboration of narrative texts, fostering creativity and imagination together ${ }^{23,24}$.

The results of psychoeducational programs are positive; there are changes in phonological knowledge and development, language as a social practice, and in semantic and morphosyntactic aspects. The evaluations carried out indicate improvement with respect to control groups in said abilities related to reading and writing ${ }^{25,26}$.

An intervention program was established based on training processes based on rehabilitation tasks in children with deficiencies in the quality of handwriting, the ability to understand and dominate the text. In the intervention, activities and active participation in reading processes (occupation and participation approach to reading intervention) were developed, which allowed to integrate different perspectives in the treatment, education, occupational cognitive psychology, and cognitive neuroscience. The results obtained showed an improvement in the objective skills of the intervention in relation to the control group $27-29$.

The results of intervention programs to reduce the difficulties associated with dyslexia are evaluated through multiple instruments that allow obtaining valid and reliable results. Software was used to train reading skills that showed positive changes in fluency, accuracy, and speed of reading, general knowledge of vocabulary and comprehension of written texts ${ }^{30}$.

In this thematic line, an intervention program that implemented visuomotor coordination exercises were carried out, which showed that the strategies were effective to improve the deficits associated with children with DD (skills of visual discrimination, visual memory, Visual Spatial Relationship, visual closure, phonological awareness, and quality of writing) ${ }^{31,32}$.

Other investigations have demonstrated the effectiveness of interventions focused on cognitive abilities (attention, memory, executive functions, and among others), using different methodological strategies and evaluating changes through instruments such as functional magnetic resonance ${ }^{33-36}$. In these studies, the effects of intervention programs on functional connectivity in areas related to learning processes in children with dyslexia and attention deficit hyperactivity (ADHD) are described. The results showed better functional connectivity in the cingulate-opercular, anterior cingulate cortex, decrease of components $\mathrm{N} 100$ and P300, as well as increase in the accuracy of the writing and decrease in the reaction time (processing speed) ${ }^{33-38}$.

Music-based programs were also identified that were intended to help improv brain circuits that are common to music and language processes, which in theory could have a positive effect on the specific difficulties in some types of dyslexia. Positive changes were evidenced in categorical and auditory perception, auditory attention, phonological awareness, reading skills, repetition of pseudowords, temporal processing, and rhythm skills ${ }^{39,40}$.

Continuing with the interventions based on improving the reading processing, specifically in the grapheme-phoneme, using essentially game strategies. Positive results were shown in the ability to read and decode words in relation to the control group ${ }^{41}$. In similar investigations, positive results were presented after the intervention program in phonetic reading, visual words, and reading fluency ${ }^{42-44}$.

On the other hand, research formulated from a rhythmic program of reading education (rhythmic reading training), contributed positive effects in the reading and speaking process (sound, word coding capacity, categorical, and auditory perception as well as in the temporal component of expression), and the authors conclude that the rhythm facilitates the development of reading skills due to the temporal structure that modulates the decoding of words ${ }^{45,46}$.

Regarding longitudinal investigations, a 5-year follow-up to a reading intervention program was carried 
out with children of the third grade of schooling $(n=2212)$, positive changes were generated in spelling, decoding of words and reading comprehension in relation to with the control group. There were no significant differences in vocabulary. For future studies, the author suggests the systematic inclusion of intervention activities but at a lower intensity, in stages that follow the development of reading skills ${ }^{47}$.

Finally, the intervention programs focused on the family are also necessary. In this sense, training aimed at parents was implemented, which consisted of information or psychoeducation on the characteristics and management of children with dyslexia, in addition to presenting strategies of promotion of prosocial behavior, aimed at reducing behavioral difficulties. In the final evaluation, the parents reported positive changes in their children's emotional and social skills based on the knowledge and implementation of the strategies learned during the program ${ }^{48,49}$.

\section{Discussion}

According to the review of literature, the various interventions in the child population show significant advances in the implementation of pedagogical strategies and cognitive stimulation through didactic games, which allow children to improve the understanding and expression of language (acquisition of vocabulary, understanding of texts, and among others). Activities related to music were also implemented to improve reading skills, the components of phonological awareness, spatial location, and indispensable aspects in the development of phonoarticulation related to the reading process.

It is important to mention that most intervention programs allowed the promotion of reading and writing skills, although the research that presented results that were not improved from the activities carried out in their intervention programs is also highlighted. The intervention processes demonstrate the effectiveness of various processes aimed at improving learning problems. Among them, the use of pedagogy, music, and cognitive stimulation is mentioned as a complement to basic school skills. This implementation allowed advances in students with learning difficulties.

In general, the investigations are highlighted for their methodological quality (pre-post or repeated measurement designs, broad samples, random assignation of the participants to the experimental and control groups, instruments with validity and reliability data, and among others). It is taken into account that despite the few results of the search conducted in Spanish in the past
10 years, the research carried out contributes to the development of increasingly specific intervention programs for children with learning disorders, including different methodological strategies. The intervention programs include children with difficult socioeconomic characteristics and contribute not only in the school environment but also in social contexts.

The studies published in English mostly present the methodological characteristics that identify a quality article. The presence of Latin American authors is highlighted in the revised articles in English, which denotes the collaboration of authors from different regions of the world to produce knowledge that contributes to the needs and/or particular difficulties of children with learning difficulties.

Finally, the articles in English and Spanish included in the results of the study differ essentially in the methodological aspects, the Latin American studies with intervention programs focused on the literacy processes in children with learning difficulties present small samples, evaluation instruments not validated in Hispanic-Latin American population and without reliability data, the children that make up each of the experimental and control groups are not randomized; therefore, the results are not generalizable.

\section{Conclusion}

The current state of empirical research published in Spanish in intervention processes in children with learning difficulties is fewer in number in the past 10 years compared to literature in English, as evidenced by the search performed. The comparison established with literature published in English indicates progressive advances of Latin American scholarship in the topic addressed in this review, specifically in intervention programs focused on specific difficulties associated with learning disorders and the characteristics presented by each of the children.

\section{References}

1. Bruner J. Desarrollo Cognitivo y Educación. Madrid: Morata; 1998.

2. Pinzás J. Metacognición y Lectura. Lima: Fondo Editorial PUCP; 2003.

3. Talero C, Espinosa A, Vélez A. Dificultad del aprendizaje de la lectura en las escuelas de una localidad de Bogotá. Acta Neurol Colomb. 2005; 21:280-8.

4. Ardila A, Rosselli M. Neuropsicología Clínica. México: Manual Moderno; 2007.

5. Matute E, Ardila M, Roselli A. Trastorno de la lectura. In: Roselli M, Matute y ME, Ardila A, editors. Neuropsicología del Desarrollo Infantil. México: Manual Moderno; 2010. p. 139-60.

6. Matute E, Roselli A, Ardila M. Trastorno de la expresión escrita. En: Roselli A, Matute y ME, Ardila A, editors. Neuropsicología del Desarrollo Infantil. México: Manual Moderno; 2010. p. 161-80.

7. Paris SG, Paris AH. Classroom applications of research on self-regulated learning. Educ Psychol. 2001;36:89-101. 


\section{Villanueva-Bonilla and AM. Ríos-Gallardo: Learning disorders}

8. Álvarez-Otero B, Monereo C. Evaluación del conocimiento estratégico de los alumnos a través de tareas auténticas de escritura en clase de ciencias naturales. Av Psicol Latinonot. 2010;28:251-64.

9. Lopera F. Dificultades del aprendizaje. In: Díaz R, Cornejo W, editors. Neurología Infantil. Medellín: Universidad de Antioquia; 2002. p. 224-42.

10. Rivas A. América Latina Después de PISA: lecciones Aprendidas de la Educación en Siete Países (2000-2015). Argentina: Fundación CIPPEC; 2015.

11. Aponte-Henao M, Zapata-Zabala ME. Caracterización de las funciones cognitivas de un grupo de estudiantes con trastornos específicos del aprendizaje en un colegio de la ciudad de Cali, Colombia. Psychologia. 2013;7:23-34

12. Sattler J, Weyandt L. Discapacidades específicas para el aprendizaje. Evaluación infantil: aplicaciones Conductuales y Clínica. Vol. 2. México: El Manual Moderno; 2003. p. 293-349.

13. Pardo NA. Prevalencia del Trastorno Específico de la Lectura en una Muestra de Instituciones Educativas de la Localidad 19 de Bogotá. Colombia: Universidad Nacional de Colombia; 2015.

14. Defior S, Serrano F. Dislexia en español: bases para su tratamiento y diagnóstico. Dislexia definición e intervención en hispanohablantes. En: Matute E, Guajardo S, editors. Dislexia: definición e Intervención en Hispanohablantes. México: Manual Moderno; 2012. p. 15-35.

15. Artigas-Pallarés J. Dislexia: enfermedad, trastorno o algo distinto. Rev Neurol. 2009;48:63-9

16. Portellano Pérez J. La Disgrafía. España: Editorial Paidós; 1985

17. Dueñas M. Tengo un Hijo Disléxico. Madrid: Temas de Hoy; 1987.

18. Fabelo S, del Carmen M. Prevención de las disgrafías escolares: necesidad de la escuela actual para la atención a la diversidad: una mirada desde Cuba. Nóesis Rev Ci Soc Humanit. 2006;15:117-33.

19. Cadavid-Ruiz N, Rosas R, Quijano-Martínez MC, Tenorio M. El juego como vehículo para mejorar las habilidades de lectura en niños con dificultad lectora. Pensamiento Psicol. 2015;12:23-38.

20. Flórez-Romero R, Restrepo MA, Schwanenflugel P. Promoción del alfabetismo inicial y prevención de las dificultades en la lectura: una experiencia pedagógica en el aula de preescolar. Av Psicol Latinonot. 2009;27:79-96.

21. Córdova E. Intervención de la lectoescritura en una niña con dislexia. Pensamiento Psicol. 2014;12:55-69.

22. Vargas A, Villamil W. Diferencias en el rendimiento lector entre dos grupos de niños de transición debidas a una intervención promotora de alfabetismo emergente en el aula. Rev Colomb Psicol. 2007;16:65-76.

23. Castilla C, Amaya MY, Amaya YP, Laguna YV. Influencia del juego como pilar de la educación en el desarrollo del lenguaje oral y escrito por medio de los juegos de mesa. Rev Iberoam Psicol. 2014;7:39-48.

24. Duque-Aristizábal $C$. Exploración de la comprensión inferencial de textos narrativos en niños de preescolar. Rev Colomb Psicol. 2010;19:21-35.

25. Morales D, de Delia J, Mota MC, García EZ. La práctica social del lenguaje como base para la enseñanza de la lectoescritura. Rev lberoam Psicol. 2012;5:59-66.

26. Valenzuela MJ, Ruiz IM, Ríos MD. Intervención temprana de la lectoescritura en sujetos con dificultades de aprendizaje. Rev Latinoam Psicol. 2011:43:35-44.

27. Grajo LC, Candler C. An occupation and participation approach to reading intervention (OPARI) Part II: pilot clinical application. J Occup Ther Sch Early Interv. 2016:9:86-98.

28. Grajo LC, Candler C. An occupation and participation approach to reading intervention (OPARI) Part I: defining reading as an occupation. $J$ Occup Ther Sch Early Interv. 2016:9:74-85.

29. Baldi S, Nunzi M, Brina CD. Efficacy of a task-based training approach in the rehabilitation of three children with poor handwriting quality: a pilot study. Percept Mot Skills. 2015;120:323-35.

30. Tucci R, Savoia V, Bertolo L, Vio C, Tressoldi PE. Efficacy and efficiency outcomes of a training to ameliorate developmental dyslexia using the online software reading trainer ${ }^{\circledR}$. BPA Appl Psychol Bull. 2015;64:53-60.
31. Qian Y, Bi HY. The effect of magnocellular-based visual-motor intervention on Chinese children with developmental dyslexia. Front Psychol. 2015;6:1-7.

32. Fusco N, Germano GD, Capellini SA. Efficacy of a perceptual and visual-motor skill intervention program for students with dyslexia. Codas. 2015;27:128-34.

33. Horowitz-Kraus T. Differential effect of cognitive training on executive functions and reading abilities in children with ADHD and in children with ADHD comorbid with reading difficulties. J Atten Disord. 2015;19:515-26.

34. Horowitz-Kraus T. Improvement in non-linguistic executive functions following reading acceleration training in children with reading difficulties: an ERP study. Trends Neurosci Educ. 2015;4:77-86.

35. Horowitz-Kraus T, DiFrancesco M, Kay B, Wang Y, Holland SK. Increased resting-state functional connectivity of visual and cognitive-control brain networks after training in children with reading difficulties. Neuroimage Clin. 2015;8:619-30.

36. Horowitz-Kraus T, Holland SK. Greater functional connectivity between reading and error-detection regions following training with the reading acceleration program in children with reading difficulties. Ann Dyslexia. 2015;65:1-23.

37. Moreau D, Waldie KE. Developmental learning disorders: from generic interventions to individualized remediation. Front Psychol. 2016;6:1-8.

38. Horowitz-Kraus T, Toro-Serey C, Difrancesco M. Increased resting-state functional connectivity in the cingulo-opercular cognitive-control network after intervention in children with reading difficulties. PLoS One. 2015;10:1-21.

39. Habib M, Lardy C, Desiles T, Commeiras C, Chobert J, Besson M, et al. Music and dyslexia: a New musical training method to improve reading and related disorders. Front Psychol. 2016;7:26

40. Flaugnacco E, Lopez L, Terribili C, Montico M, Zoia S, Schön D, et al. Music training increases phonological awareness and reading skills in developmental dyslexia: a randomized control trial. PLoS One. 2015; 10:e0138715

41. Jeffes B. Raising the reading skills of secondary-age students with severe and persistent reading difficulties: evaluation of the efficacy and implementation of a phonics-based intervention programme. Educ Psychol Pract. 2016:32:73-84.

42. Fraga-Gonzalez G, Zaric G, Tijms J, Bonte M, Blomert L, Leppanen P, et al. Responsivity to dyslexia training indexed by the $\mathrm{N} 170$ amplitude of the brain potential elicited by word reading. Brain Cogn. 2016;106:42-54.

43. McArthur G, Castles A, Kohnen S, Larsen L, Jones K, Anandakumar T, et al. Sight word and phonics training in children with dyslexia. J Learn Disabil. 2015:48:391-407.

44. McArthur G, Kohnen S, Jones K, Eve P, Banales E, Larsen L, et al. Replicability of sight word training and phonics training in poor readers: a randomised controlled trial. Peer J. 2015;2015:1-21.

45. Bonacina S, Cancer A, Lanzi PL, Lorusso ML, Antonietti A. Improving reading skills in students with dyslexia: the efficacy of a sublexical training with rhythmic background. Front Psychol 2015;6:1510.

46. Cancer A, Bonacina S, Lorusso ML, Lanzi PL, Antonietti A Rhythmic reading training (RRT): a computer-assisted intervention program for dyslexia. In: Giakoumis D, Lopez G, Matic A, Serino S, Cipresso P, editors. $5^{\text {th }}$ International Conference on Pervasive Computing Paradigms for Mental Health, Mind Care 2015. Tokyo, Japan: Springer Verlag; 2016. p. 249-58.

47. Wolff $U$. Effects of a randomized reading intervention study aimed at 9-year-olds: a 5-year follow-up. Dyslexia. 2016;22:85-100.

48. Heim S, Pape-Neumann J, van Ermingen-Marbach $M$, Brinkhaus $M$, Grande M. Shared vs. specific brain activation changes in dyslexia after training of phonology, attention, or reading. Brain Struct Funct. 2015; 220:2191-207.

49. Multhauf $B$, Buschmann A. Parent training programme for dyslexia recognising changes in children's behaviour. LOGOS Interdiszip. 2016;24:4-14 